\title{
Dilemmas in Organising the Labour Market, Experiences with Flexicurity in the Netherlands
}

\author{
Frans Pennings
}

\begin{abstract}
Flexicurity is used as a strategy in the Netherlands in order to increase flexibility for the permanent workers and improve the position of the flexible workers. The concept was introduced in the 1990s by the government in a paper and was further elaborated in an agreement of both sides of industry. This involved that the position of temporary agency workers was regulated and improved, and it was made easier to provide contracts for a definite period. This agreement was laid down in an act, thus amending the existing labour code. Important was that the position of the trade unions was reinforced since the Act allowed deviation from the general rules only by a collective labour agreement.

In 2013, again the social partners were asked to negotiate on the flexibilisation of dismissal law and improving the position of flexible workers. This led to an agreement of the social partners and was subsequently laid down in the labour code.

This procedure is relatively successful but leaves some dilemmas untouched, such as it is easier for employers to make use of the flexibilisation of the position of permanent workers than for flexible workers to make use of the rules that are meant as an improvement. Most of them can be escaped, e.g., by employing the workers shorter than the threshold for improving their position. This may sometimes even mean that flexible workers are worse off since they lose their work sooner than they did under the old rules.
\end{abstract}

\section{The Concept of Flexicurity in the Netherlands}

Flexicurity is a term that has several meanings. In Denmark, the term is used to describe the situation of the labour market, i.e., that already for decades there is a situation where it is relatively easy to dismiss persons, but these persons are awarded a relatively generous unemployment benefit and also training in order to be able to find new work soon. In the Netherlands, the term is used differently since there is no

\footnotetext{
F. Pennings $(\bowtie)$

Utrecht University, Urecht, The Netherlands

e-mail: f.pennings@uu.nl
} 
such situation as in Denmark. Instead, since the 1980s, more and more persons are working in a flexible employment relationship, including as a temporary agency worker, an on-call worker or on a contract for a definite period. Such flexible work contracts are not prohibited by the Dutch labour law (as laid down in the Burgerlijk Wetboek (Civil Code). The Act only defines what is meant by a contract of employment and does not prohibit temporary agency workers or on-call workers. Since these flexible workers were engaged next to persons with a permanent contract, the division between workers became clear, and the differences between the various categories became to be seen as problematic by the government in the 1990s. Still, they did not want to prohibit flexible relationships, but it considered that the increased competition in the world and changing demands of enterprises and consumers required flexibility. On the one hand, it was argued that some workers with a permanent contract showed too little flexibility, e.g., in terms of working hours or changes in the work they can be obliged to do. On the other hand, the position of flexible workers was considered as too insecure. This division of the labour market was therefore becoming a serious problem.

The then Minister of Social Affairs published a green paper, Nota Flexibiliteit en Zekerheid (Paper on Flexibility and Security), ${ }^{1}$ containing the view that employers need a certain level of flexibility, and this need was increasing due to globalisation and increased competition. On the other hand, the position of the flexible workers needs improvements since their position was often quite insecure. The Paper introduced flexicurity as a strategy, i.e. trying to increase flexibility of persons with a permanent contract and creating more security for the flexible workers. This was not done by changing the labour code and prohibiting particular forms of flexibility and changing the position of the permanent workers. Probably this would have led to too much opposition of both employers and employees.

Instead, the Stichting van de Arbeid (Labour Foundation) was asked to come to an agreement on this issue. This is a private institution founded by employers' and employees' organisations for their mutual cooperation. This bipartite national body discusses developments on the labour market and sometimes issues recommendations on particular issues. These recommendations are not binding but can be elaborated in collective labour agreements on the sectorial level. Now, they were asked to negotiate on flexibility and security. These negotiations led to an advice on 3 April 1996, which was unanimous. ${ }^{2}$ An important aspect was that it was a coherent package deal. On some elements, more flexibility was allowed, such as on the renewal of contracts for a definite period. On the other hand, the position of the on-call workers was improved (see below). It was also proposed to improve the position of temporary agency workers.

The fact that it was a package deal implied that the parties involved would not accept that some elements were taken out of the package; after all it was a compromise between various interests. The government had been unofficially represented in

\footnotetext{
${ }^{1}$ Kamerstukken II (Parliamentary Papers) 1995-1996, 24,543.

${ }^{2}$ Flexibiliteit en Zekerheid, The Hague 1996.
} 
the negotiating process in order to make sure that the outcome was acceptable when it would come to legislation.

This advice on flexicurity was elaborated in legislation, the Act Flexibiliteit en zekerheid $^{3}$ (Act Flexibility and Security, in fact amending the labour Act) and the Wet allocatie van arbeidskrachten door intermediairs (Act on Temporary Agency Work). ${ }^{4}$

The Act Flexibiliteit en Zekerheid was a milestone in thinking on flexibility as it did not consider flexibility and security as opposed to each other but as a combination that may facilitate more flexibility by creating more security. After all, if you get a new job with attractive work and a good wage immediately after losing your old job or if you get a generous unemployment benefit with a guarantee of having a job after a training period, you will be much less inclined, or maybe not all, to oppose your being given notice.

Flexicurity thus means that a compromise is made between flexibility and security, which compromise has to be reached in negotiations between both sides of industry (see also Van Velzen and Wilthagen 2006).

It is important to remain cautious in respect of the results of flexicurity negotiations since measures to increase or keep flexibility and measures to promote security are not of exactly the same order. Suppose that a measure allows employers to provide more contracts for a definite period on a row in exchange for the obligation to give temporary agency workers the right to a permanent contract after 78 weeks. In that case, employers can make use of the larger room for contracts for a definite period, whereas temporary agency workers can still be dismissed after 76 weeks.

\section{Temporary Agency Workers}

An important element of the Agreement of the Stichting van de Arbeid was the position of temporary agency workers. The Agreement confirmed that these workers are working under a contract of employment. So far, there had been uncertainty on their legal status since they were in fact working for another party, who gives the actual instruction on the work to be done, than the formal employer (the temporary work agency); could this be a contract of employment? The Agreement, and later the implementing Act, laid down the statutory rule that this was to be seen as a contract of employment with the temporary work agency. As a result, labour law was applicable to them unless the Act allows deviations because of their specific position. It was now also certain that that they can rely on social security schemes applicable to employees.

In collective and individual labour agreements of temporary agency workers, it was laid down that their contract of employment ends as soon as the user no longer

\footnotetext{
${ }^{3}$ Act of 14 May 1988, Stb. (Official Journal) 300.

${ }^{4}$ Act of 4 June 1996, Stb. (Official Journal) 306.
} 
needs the work of the temporary agency worker. It was also provided in their contracts that the contract ends as soon as the worker falls ill. As a result, the employment protection is still different from that of regular workers; social security benefits compensate the income loss in such cases, provided that the conditions are fulfilled.

The position of the temporary agency worker was improved by the fact that the general labour law was applicable to them and that for deviations, a collective labour agreement is necessary. An important general rule laid down in the Civil Code is that the employer has to continue to pay wages even if there is no work. This rule can be deviated from by an individual labour agreement, but that is possible for 6 months only. For the period after these 6 months, a collective agreement is necessary to deviate from the statutory rule. Also for the extension of contracts for a definite period (if more than three extensions were needed), a collective agreement is necessary. As we have seen supra, temporary work agencies often give temporary agency workers many contracts for a definite period on a row; for instance, when their contract ends due to sickness or ending of the work for a user and they are reinstated for a new user, a new contract is given.

The need for a collective agreement in order to deviate from the Act has reinforced the position of the trade unions considerably, which reinforcement is very important, since the unionisation rate of flexible workers is very low.

Trade unions then made use of their bargaining power to introduce pension provisions for temporary agency workers and possibilities to follow training. Another element was that the legal position of the agency workers was improved if they worked longer for a particular agency. These provisions have changed through time. But to give an idea of the situation during the first agreements, after 6 months of work for an agency, they were given a contract of employment for 3 months (so this did not end if there was no work or if they became ill). After another 26 weeks, they were given a contract for an indefinite period.

However, agencies can evade the obligation to provide a contract with a better legal position by dismissing the agency workers before they reach a phase in which this stronger position has to be given. Only if it is obvious that a certain person is of high value for the agency (e.g., a highly specialised worker, for whom there will always be work) will a person be employed under a contract for an indefinite period.

So there is a permanent tension between the need for flexibility and the wish to improve security.

In later collective agreements, the duration of the periods before a better legal position is given were changed (it took longer before the position was improved), but the idea was clear: the longer one worked for an agency, the stronger the position.

Since collective agreements are needed to deviate from statutory rules, new trade unions were established that offered to make collective labour agreements with weaker legal positions for temporary agency workers. Some of these unions were even created by employers, and some of these tried to earn money by offering such collective agreements. However, for the government, it is important that the system was not undermined by unrepresentative or yellow unions. 
The main collective agreement for temporary agency workers (the so-called ABU collective agreement) was declared generally binding by the minister, and there was only room for alternative collective agreements for temporary agency workers if they were provided exemption from the ABU agreement. For this purpose, it was required that the unions were representative enough and the conditions satisfactory; this exemption was not easily given. Still this phenomenon shows that if the method of reinforcing the position of unions by giving collective agreements the possibility to deviate from the Act is chosen, regulations are needed to prevent the undermining of the system.

\section{The Reform of Dismissal Law in 2015}

This method of finding a balance between flexibility and security was used again in 2013, when the government wanted to amend the dismissal law. This had been a very complicated issue, and several commissions had issued proposals and reports, but so far none of these had been accepted.

The Minister of Social Affairs now again followed the approach that the Stichting van de Arbeid was asked to make an agreement on this issue, with at-the-background government officials following the negotiations. In 2013, indeed an agreement was reached (Sociaal Akkoord), which was elaborated in a bill for Parliament and finally reached the statute book, Wet werk en Zekerheid (Act on Work and Security).

This form of cooperation between social partners and the government was criticised in Parliament since it meant that the room for Parliament to amend the bill is quite small. Of course, formally they had the room for amending the bill, but then social partners could claim that the agreement was not valid anymore. So this was a dilemma for Parliament.

However, without the support of the social partners, it appears to be very difficult to realise important changes on the labour market, so the Act followed the Agreement closely, and if deviations were necessary, there were new negotiations with the social partners.

One important element relevant of the Agreement is that the rules on the dismissal payments were changed, until the change persons whose contract was dissolved by the court could be given a high dismissal payment. It was up to the judge to decide, although the association of judges had made policy rules in order to reach some uniformity. Employers often complained that these payments were high. Another problem was that persons whose contract has ended after they were given notice by their employer (after having obtained a permit from the employment office) did not receive any compensation. Also, persons on a contract for a definite period did not receive compensation when their contract ended. These differences were found unjustified. The Agreement introduced a much lower dismissal compensation, now payable to all persons who have been employed for at least 2 years, regardless of how their contract ends. So now also in case of a person working for a definite contract, such payment is due. To be more precise, the term dismissal compensation 
is not used anymore, but the payment is called transition payment. The idea is that it can-but does not have to- be used to qualify the employee better for a new job, for instance by letting him follow a training. Preferably this is done during the years, and employers who have indeed spent money on such measures can, under certain conditions, deduct these costs form the transition payment.

Since the Act is still quite young (it came in force on 1 July 2015), it is not clear yet what the effects really are of this payment.

In any case, however, this new approach fits in the flexicurity concept. The old dismissal payments (payable to persons on a permanent contract, and the longer they have been on a contract the higher they were) were often seen as an impediment to change jobs as one loses the right to such payment when one accepts a new job. In case of a job change, the calculation of the number of years relevant to the level of the payment starts again, so this may discourage changing jobs. This effect still exists with the transition payment, but since it is often lower, the effect will be much smaller. An important improvement is the position of flexible workers since they may now also be paid such a payment. Of course, employers may try to escape this by offering contracts for a little less than 2 years, but basically there is no exclusion anymore of contracts for a definite period.

Also, the rules on the extension of contracts for a definite period were changed. Before the change, it was possible to renew a contract three times before it became a contract for an indefinite period or if the total length after the extension was more than 36 months. This meant that persons could remain in an uncertain position for a long time.

The new rules are that contracts can be extended two times (instead of three) only; moreover, the extension cannot exceed 24 months (instead of 36 months). The idea behind this is that persons are sooner given a contract for an indefinite period. Still, the extension can be given by a collective agreement, although these possibilities, which were unlimited under the old rules, are now restricted. It now provides that 24 months can be extended to 48 months and that the series of contracts can be extended to six if it is a contract of a temporary work agency or if the intrinsic nature of the work requires the extension.

Another improvement is that no longer is a non-competition clause allowed in a contract for a definite period, unless it appears from the arguments given by the employer in writing that the clause is necessary because of weighty interests of the company. What this will mean in practice is still unclear. But in any case, the judge can test the arguments given by the employer, and the burden of proof is with the employer.

The idea behind this new rule is that the non-competition clause is no longer seen as justified if a person is given a contract for a definite period only.

These measures - transition payments and no longer allowing a non-competition clause-make workers on a contract for a definite period more expensive or less attractive, and this may make the gap between persons working on a contract for an indefinite period and those working on a definite time contract smaller. 


\section{On-Call Workers}

Also, the position of on-call workers is improved. The Act of Flexibility and Security provides that if a person has worked during 3 months in all weeks or at least $20 \mathrm{~h}$ a month for the same person or company, there is a legal presumption that there is a contract of employment (Article 7:610a Bw). Article 7:610b Bw provides that if there is no defined number of working hours, there is a legal presumption that the average number of the last 3 months is the extent of the contract. Employers can refute the assumption by saying that the last 3 months are not representative (for instance, because it was an exceptional busy period (e.g., preparation for Christmas), but this means that they have the burden of proof.

In addition, the position of on-call workers is often seen as unsatisfactory since they are often uncertain on whether they will receive a call to work, and if this is not the case they have no income. Sometimes they may be asked to work for a very short time only, e.g. for an hour, and that is, in particular, problematic if they have long travelling times or when their other activities are interrupted.

The Act on Flexibility and Security provides that on-call workers have to be paid for at least $3 \mathrm{~h}$ in each call, even if the call is for fewer hours.

These rules appeared to have the effect that making use of on-call workers became less attractive to employers, and they now seem to make more use of temporary agency workers.

\section{Self-Employed Persons}

Another issue related to flexibility is that of self-employed workers, i.e. selfemployed without staff. Their number has increased considerably in the past 10 years. Making use of these workers has important advantages for employers since dismissal law is not applicable, and in case of sickness they do not have to continue to pay wages. Social security contributions do not have to be paid for them since these contributions are due for employees only. For workers, it may (seem to) be attractive to work as self-employed since they have a considerable higher net income than when employees' social security contributions are deducted. However, in periods of an economic crisis or in case of personal misfortune, such as long-term sickness or invalidity, they are not protected by solidarity schemes. Often they do not have private insurance either since the contributions for private schemes are high in relation to their income.

Of course for the 'real' self-employed person, the responsibility to make provisions and to have the advantages and also disadvantages of entrepreneurship is part of their choice. However, for those whose business is extremely low-and there are a lot of persons with a small business - the risks of becoming disabled or ill are very hard to bear. There is also a category of persons who in fact work for one company only and therefore closely resemble employees. Sometimes these are workers who 
were dismissed and later re-engaged as self-employed by the same company. Many of these are in fact dependent on one principal and should be treated as employees.

Although at first sight self-employed persons do not seem to fit in the category of flexible workers, since they are not employees, the use that is made of them indeed fits in the growing flexibilisation of the labour market, and their use may undermine the position of the workers. Therefore, it is important to take them into account as well.

An attempt to set minimum rates for these self-employed so that they do not undermine the minimum wages for employees was not accepted by the Court of Justice in the FNV Kiem Judgment. ${ }^{5}$ If a person is really self-employed, the competition provisions of the Treaty on the Functioning of the EU prohibit price arrangements. However, the Court of Justice has made it easier to make rules in collective agreements on the bogus self-employed (see Pennings 2015). It provides that a service provider can lose his status of an independent trader, and hence of an undertaking, if he does not determine independently his own conduct on the market, but is entirely dependent on his principal, because he does not bear any of the financial or commercial risks arising out of the latter's activity and operates as an auxiliary within the principal's undertaking. The status of 'worker' within the meaning of EU law is not affected by the fact that a person has been hired as a self-employed person under national law, for tax, administrative or organisational reasons, as long as that persons acts under the direction of his employer as regards, in particular, his freedom to choose the time, place and content of his work. These broad criteria may enable social partners to include bogus self-employed, for whom it could be difficult to prove that they are employees, under the collective agreement. In the Dutch situation, such arrangements are now being tried to be made; a recent collective agreement with such provisions was made for architects. ${ }^{6}$ Of course, for such agreements, cooperation of both sides of industry is essential.

Another interesting new development was seen in the situation of the postmen. When the post office company was privatised, it began to reduce labour costs considerably and to engage more and more self-employed persons, who are paid on a piece-rate basis. This led to low incomes; fewer and fewer clients are at home when the packet is delivered, and in such case they were not paid.

Very recently, the post office company became aware that more experienced and reliable postmen are needed since more and more people are not at home when the packets are delivered. For the purpose, solutions are to be found, e.g. by giving a key to the postmen to deliver the packages. In order to make this acceptable, a relationship has to be developed between the postmen and their clients, so the postmen are trusted in executing this task. Long-term relationship is now seen as necessary, and for this reason the postmen are offered a contract of employment. Market developments can thus influence the way back to contracts of employment. It is too early to know

\footnotetext{
${ }^{5}$ Case C-413/13, FNV Kiem, ECLI:EU:C:2014:2411.

${ }^{6} \mathrm{http}: / /$ www.bna.nl/bna-in-de-media-primeur-cao-zzp-architecten/ last visited on 11 July 2016.
} 
whether this will become a broader phenomenon, but it may very well be in a society where services are becoming more and more important.

\section{Conclusions}

Flexicurity in the Netherlands is an approach in which it is envisaged to keep flexibility in the labour market since it is generally accepted that employers need this flexibility. There are no absolute prohibitions of particular forms of flexible contracts (whereas this was the case in other countries, e.g. with temporary agency work), but in some cases judges may decide that a person is not really a selfemployed person and then the labour law rules have to be followed.

Interesting is the way how flexicurity is introduced. Apparently, a top-down approach does not fit with the labour market; instead, most important changes must have the form of negotiations between both sides of industry. In this way, a balance can be found between employers' and employees' interests.

Moreover, it is interesting to reinforce the position of trade unions by making a collective agreement necessary for the functioning of the company since otherwise, the labour Act would be too restrictive.

There are also other statutory techniques. The legal presumption that there is a contract of employment or that one is engaged for a particular number of working hours is an important support for workers. It may also mean that there is then a shift from one particular contract to another type.

A third approach is by making flexible workers more expensive or, in other words, by decreasing the difference in costs between flexible and permanent workers. This can be done by setting minimum rates in case of bogus self-employed, by requiring particular forms of social security for all workers, including the selfemployed, and, in some cases, by removing rules that make employees more expensive than necessary.

We have seen that measures were taken that may improve the position of flexible workers and have weakened the position of permanent workers to some extent. However, it remains possible for employers to escape the rules improving the position of flexible workers, for instance by giving contracts that are below the thresholds for the applicable rights, such as the transition payment. As a result, although there is now more protection, the balance remains insecure since, after all, the need for flexibility of employers makes them creative in finding solutions. In any case, however, extreme situations are addressed, such as calls for less than $3 \mathrm{~h}$, and some protection is given.

In this framework of a labour market where flexibility is allowed, although it is tried to get it under some control, there remain some difficult dilemmas. One of these is that if one improves the position of flexible workers, for instance by restricting the possibility to renew the contract for a definite period, they may sooner have to leave this employer if the employer does not want to provide a permanent contract. A second phenomenon may be a shift from one type of contract to another. An example 
was the improved protection of on-call workers, which led to a shift to temporary agency workers. Although the shift was not problematic as such, since the legal position of the temporary agency worker is somewhat more attractive, it meant loss of work for middle-aged women in favour of young persons, who were more easily recruited by temporary work agencies. Such dilemmas are difficult to solve and are in line with the continuing seeking of a balance between flexibility and security.

\section{References}

Pennings F (2015) Exceptie van de mededingingsbepalingen voor (schijn)zelfstandigen: de zaak FNV Kiem. Nederlands tijdschrift voor Europees recht, 2015(4)

van Velzen M, Wilthagen T (2006) In search of a balance: flexibility and security strategies in employment protection legislation, temporary work and part-time work. In: Pennings F, Süral N (eds) Flexibilisation and modernisation of the Turkish Labour market. Alphen aan den Rijn, pp 153-182 